\title{
AIRBORNE PEPTIDOGLYCANS AS A SUPPORTING INDICATOR OF BACTERIAL CONTAMINATION IN A METAL PROCESSING PLANT
}

\author{
MARCIN CYPROWSKI, ANNA ŁAWNICZEK-WAŁCZYK, and RAFAŁ L. GÓRNY \\ Central Institute for Labour Protection - National Research Institute, Warszawa, Poland \\ Department of Chemical, Aerosol, and Biological Hazards
}

\begin{abstract}
Objectives: The aim of this study was to assess exposure to airborne endotoxins and peptidoglycans (PGs) as well as possibility of using PGs as a surrogate measure of bacterial exposure in workplaces in a metal processing plant. Material and Methods: Personal dosimetry $(\mathrm{N}=11)$ was used to obtain data on concentrations of viable bacteria, total number of bioaerosol particles, endotoxins and peptidoglycans. To investigate the size distributions of aerosol particles responsible for transport of endotoxins and PGs, air samples $(\mathrm{N}=5)$ were additionally collected using the 8-stage cascade impactor. Endotoxins and PGs were assayed with the Limulus amebocyte lysate (LAL) test and a kinetic version of the silkworm larvae plasma (SLP) test, respectively. Results: Median concentrations of airborne PGs $\left(14.6 \mathrm{ng} / \mathrm{m}^{3}\right)$, endotoxins $\left(0.2 \mathrm{ng} / \mathrm{m}^{3}\right)$, viable bacteria $\left(1.16 \times 10^{3} \mathrm{CFU} / \mathrm{m}^{3}\right)$ and the total number of bioaerosol particles $\left(1.81 \times 10^{6} \mathrm{cell} / \mathrm{s} / \mathrm{m}^{3}\right)$ were determined. Qualitative analysis revealed presence of 19 bacterial species belonging to 14 genera. The calculations showed strong, significant correlations $(\mathrm{p}<0.05)$ between endotoxins, viable bacteria $(\mathrm{r}=0.75)$ and the total number of bioaerosol particle concentrations $(r=0.76)$ as well as between PGs and the total number of bioaerosol particle concentrations $(r=0.72)$. Size distribution analysis showed that the highest concentrations of bacterial aerosols occurred in the range of 2.1-3.3 $\mu \mathrm{m}$. In the case of endotoxins, an increase of concentrations in 2 ranges of aerodynamic diameters: $1.1-3.3 \mu \mathrm{m}$ and $5.8-9 \mu \mathrm{m}$ was shown. For PGs there was a visible gradual increase of their concentrations in the range 2.1-9 $\mu \mathrm{m}$. Conclusions: Peptidoglycans can be treated as a supporting indicator of bacterial contamination in metal processing plants, particularly when an assessment of an immunotoxic potential of microbiological hazards needs to be performed. However, to be extrapolated to other occupational and non-occupational environments, the obtained results require a further verification.
\end{abstract}

Key words:

Metalworking fluids, Peptidoglycans, Endotoxins, Exposure assessment, Size distribution, Airborne bacteria

\section{INTRODUCTION}

Metalworking fluids (MWF), used in industrial processes usually as water emulsions with organic compound additives, form an excellent environment supporting microbial growth, especially bacteria [1]. The hitherto obtained results have shown that, maximum concentrations of bacteria in MWF can range from $10^{6} \mathrm{CFU} / \mathrm{ml}$ to $10^{10} \mathrm{CFU} / \mathrm{ml}$ [2-5]. In numerous industrial processes (such as grinding or cutting), a rapid rotation of metalworking tools may result in a release of oil mist and a subsequent emission of biological particles into the air. Concentrations of culturable airborne bacteria are, however, characterized by a significant variability from $10^{1} \mathrm{CFU} / \mathrm{m}^{3}$ to $10^{5} \mathrm{CFU} / \mathrm{m}^{3}[6-8]$.

The project was supported by the Central Institute for Labour Protection - National Research Institute under Grant No. I-35 "Peptidoglycan as a new indicator of bacterial contamination of the working environment." Project manager: Marcin Cyprowski, Ph.D.

Received: January 29, 2015. Accepted: June 24, 2015.

Corresponding author: M. Cyprowski, Central Institute for Labour Protection - National Research Institute, Department of Chemical, Aerosol, and Biological Hazards, Czerniakowska 16, 00-701 Warszawa, Poland (e-mail: macyp@o2.pl). 
Harmful effect of bacteria on exposed workers can be seen from the angle of their infectious, allergenic and immunotoxic properties. Evaluation of their infectious and allergenic potential is usually associated with conducting a detailed qualitative analysis that allows identification of a particular genus/species. However, immunotoxic properties are not related to viability of biological particles, and their assessment may include viable micro-organisms from different taxonomic groups, dead intact cells as well as their fragments. From the human health point of view, one of the most important cell wall components of bacterial origin are endotoxins and peptidoglycans [9]. Ability to recognize both these pathogens associated molecular patterns (PAMPs) by the human's immune system decides about health status of the exposed individuals.

Knowledge of bacterial endotoxins should be considered as well established. After many years of research, these biologically active lipopolysaccharides (LPS) are generally treated as a good predictive factor of exposure to Gram-negative bacteria, in both occupational (particularly characterized by high concentrations of organic dust) as well as non-occupational (homes, schools, etc.) environments [10]. Presence of endotoxins has been also confirmed in the metal industry, where their concentrations reached $5 \times 10^{5} \mathrm{EU} / \mathrm{ml}$ (EU - endotoxin unit) in MWF $[3,5,11,12]$ and hundreds $\mathrm{EU} / \mathrm{m}^{3}$ in the air $[5,6,8,11]$. Adverse health effects caused by endotoxins, such as: inflammatory reactions, systemic effects and decrease in a lung function, are also well evaluated [13]. On the basis of both chronic and acute study results and taking into account a "dose-response" relationship, some researchers have proposed a health-based recommended exposure limit for endotoxins in the workplace [14].

Examination of peptidoglycans in the work environment is not yet as prevalent as in the case of endotoxins [15-17]. Peptidoglycans (PGs) are the major component of a bacterial cell wall, composed of amino sugars (muramic acid and $N$-acetylglucosamine) and a tetrapeptide. It is estimated that they may constitute up to $70 \%$ of the Gram-positive bacteria cell wall. In Gram-negative bacteria, PGs are also present, but in lower amounts - up to $25 \%$ [18]. Compared to bacterial endotoxins, knowledge about peptidoglycan's adverse effects on human health is much less understood. Numerous studies have shown that PGs can induce production of inflammatory markers [19]. It is suggested that peptidoglycans play a significant role in the pathogenesis of complex bacterial infections enhancing biological activity of endotoxins [20]. Presence of peptidoglycans in MWF has been recently confirmed [21]; however their concentrations varied in the broad range - 3.4-427 ng/ml.

The aim of this study was to assess exposure to airborne endotoxins and peptidoglycans as well as to assess the possibility to use PGs as a surrogate measure of bacterial exposure in workplaces in a metal processing plant in comparison with another inflammatory marker, i.e., endotoxins.

\section{MATERIAL AND METHODS}

\section{Sampling sites}

Measurements of bioaerosols were carried out in a factory of cooking equipment. A detailed description of sampling points was shown in Table 1. In total, 5 sampling points were chosen, of which 4 (L1-L4) included workplaces with metal-finishing machines, which were grouped in 1 part of the manufacturing hall, and the distance between them did not exceed $3 \mathrm{~m}$. The sampling point L5 was located approximately $25 \mathrm{~m}$ from the tested metal-finishing machines, where some manufactured items were stored. Additionally, to control the influence of external microbial sources on the indoor microbiome, outdoor (background) samples (L6) $10 \mathrm{~m}$ from the entrance to the office building (approx. $50 \mathrm{~m}$ from manufacturing hall) were also taken.

\section{Sampling methods}

Personal dosimetry was used to obtain data on concentrations of viable (understood here as culturable) bacteria, 
Table 1. Sampling points in the metal processing plant

\begin{tabular}{llcc}
\hline \multicolumn{1}{c}{ Sampling point } & Description & Temperature & Relative humidity \\
& & {$\left[{ }^{\circ} \mathrm{C}\right]$} & 37 \\
\hline L1 & grinder & 20.9 & 37 \\
L2 & hand lathe 1 & 21.0 & 31 \\
L3 & numerically controlled lathe & 22.4 & 32 \\
L4 & hand lathe 2 & 22.2 & 31 \\
L5 & storing place & 23.9 & 43 \\
L6 & outdoor background & 19.5 & \\
\hline
\end{tabular}

the total number of bioaerosol particles (viable and nonviable together), endotoxins and peptidoglycans. Air samples were collected by the use of the Button Personal Inhalable Aerosol Sampler ${ }^{\circledR}$ (BS) (SKC Ltd., Eighty Four, PA, USA) connected to a universal aspirator (model Gilian 5000, Sensidyne, Inc., St. Petersburg, FL, USA) with a calibrated air flow of $5 \mathrm{l} / \mathrm{min}$ [22]. During the measurement, 2 BSs were mounted on a special harness, over an employee's chest assumed so that the filter cartridges were at the height of human breathing zone, except for the samples L5-L6, where the measurement sets (i.e., filter holder plus pump) were fixed to a tripod. In order to assess concentrations of endotoxins and peptidoglycans, the 1st BS was filled out with $25 \mathrm{~mm}$ Teflon filter (PTFE) with a pore diameter of $0.5 \mu \mathrm{m}$ (SKC Ltd., Eighty Four, PA, USA), and the air sample was collected for $60 \mathrm{~min}$. To quantify and identify airborne bacteria, the 2nd BS was filled out with a $25 \mathrm{~mm}$ gelatin filter with a pore diameter $3 \mu \mathrm{m}$ (SKC Ltd., Eighty Four, PA, USA) and the sample was collected for $30 \mathrm{~min}$.

In total, 2 measurement series were carried out during the spring and autumn seasons, when 11 air samples of each kind were collected. Unfortunately, due to a failure of pumps during measurements of background samples, these results were excluded from the analysis. After the sampling, the filters were transferred into sterile containers placed into a travel freezer. In the laboratory, gelatin filters were immediately taken for a further analysis and PTFE filters were stored frozen at $-20^{\circ} \mathrm{C}$ until a full analysis of endotoxins and peptidoglycans.

To investigate the size distributions of aerosol particles responsible for transport of endotoxins and peptidoglycans, the air samples were additionally collected using the 8-stage cascade impactor (model 20-830, New Star Environmental, Inc., Roswell, GA, USA), which can separate particles of the following aerodynamic diameters: 0.4/0.7/1.1/2.1/3.3/4.7/5.8/9 $\mu$ m. At each stage of the impactor membrane, a glass fiber filter (GF/A, pores $1.6 \mu \mathrm{m}$ ) with a diameter of $81 \mathrm{~mm}$ was placed. In order to remove potential microbial contamination that could be present on the filters, the filters were subjected to depyrogenation by high temperature exposure $\left(180^{\circ} \mathrm{C}\right.$ for a minimum of $3 \mathrm{~h}$ ). The sampling was performed for $30 \mathrm{~min}$ with the airflow of $28.3 \mathrm{l} / \mathrm{min}$.

In order to identify the size distribution of bacterial particles, the 6-stage Andersen impactor (model 10-710, Graseby-Andersen, Inc., Smyrna, GA, USA), which can separate particles of the following aerodynamic diameters: 0.65/1.1/2.1/3.3/4.7/7 $\mu \mathrm{m}$, was used. The impactor was loaded with Petri plates containing Tryptic Soy Agar (TSA) with 5\% additive of sheep blood (bioMérieux, Marcy l'Etoile, France). The sampling flow rate was $28.3 \mathrm{l} / \mathrm{min}$ and the sampling time was $5 \mathrm{~min}$. Both impactors for solid and biological particles were placed at the distance of $1 \mathrm{~m}$ from the metal-finishing machines and at $1.5 \mathrm{~m}$ above the ground level to simulate aspiration from a worker's 
breathing zone. In total, the measurements were carried out during the spring season, when 6 air samples of each kind were collected. At each sampling point, temperature and relative humidity were also measured by the use of a portable thermo-hygrometer TFA 30.5024 (Conrad Electronic GmbH, Hirschau, Germany).

\section{Laboratory analysis of the samples}

In order to analyze concentrations of endotoxins and peptidoglycans, frozen filters were warmed up to room temperature and then subsequently eluted with $10 \mathrm{ml}$ of Limulus amebocyte lysate (LAL) reagent water (Lonza, Ltd., Basel, Switzerland) with 0.05\% Tween 20 (SigmaAldrich, Ltd., Poznań, Poland) on a platform shaker Tetramax 1000 (Heidolph, Schwabach, Germany) for $15 \mathrm{~min}$, and centrifuged with a force of $1000 \times \mathrm{g}$ for another $15 \mathrm{~min}$. Endotoxins were assayed with the LAL test in a kinetic, chromogenic version (Lonza, Ltd.). Their concentrations were measured with a temperature-controlled microplate reader Biotek Synergy 2 (BioTek, Inc., Winoos$\mathrm{ki}, \mathrm{VT}, \mathrm{USA}$ ) at a wavelength of $405 \mathrm{~nm}$ in $37^{\circ} \mathrm{C}$. The results were obtained by comparing the samples to the standard curve ranging 100-0.049 EU/ml, which was generated from 2-fold serial dilutions of control standard endotoxin (CSE) Escherichia coli 055:B5 with activity of 15 EU/ng. Peptidoglycans were spectrophotometrically determined using a kinetic version of the silkworm larvae plasma (SLP) test (Wako Pure Chemical Industries, Ltd., Osaka, Japan). After adding equal amounts $(50 \mu \mathrm{l})$ of the samples and the SLP reagent, PG concentrations were measured at a wavelength of $650 \mathrm{~nm}$ in $30^{\circ} \mathrm{C}$, during $90 \mathrm{~min}$. The results were obtained by comparing the samples to the standard curve ranging 1000-1.953 ng/ml. Both endotoxin and peptidoglycan concentrations were expressed in nanograms per cubic meter of the air $\left(\mathrm{ng} / \mathrm{m}^{3}\right)$.

Gelatin filters were eluted in sterile tubes containing $20 \mathrm{ml}$ of $0.85 \%$ sodium chloride $(\mathrm{NaCl})$ solution for $10 \mathrm{~min}$ on the same platform shaker as the PTFE filters. Part of the obtained supernatant $(5 \mathrm{ml})$ was plated on TSA with $5 \%$ additive of sheep blood. The prepared Petri plates as well as the plates from the 6-stage Andersen impactor were incubated under the following conditions: 1 day $\left(37^{\circ} \mathrm{C}\right)+3$ days $\left(22^{\circ} \mathrm{C}\right)+3$ days $\left(4^{\circ} \mathrm{C}\right)$, to allow development of a whole spectrum of bacterial strains including psychrophilic ones. Concentrations of viable bacteria were expressed as colony forming units per cubic meter of air $\left(\mathrm{CFU} / \mathrm{m}^{3}\right)$. Microorganisms isolated from the air samples were identified to the genus and/ or species level using the following API tests (bioMérieux): 20 Staph, 20 Strep, 20 NE, 20 E, 50 CHB/E and Coryne.

In order to determine the total number of bioaerosol particles (TNBP), the 2nd part of the supernatant was analyzed by the Collection of Airborne Micro-organisms on Nuclepore filters, Estimation and Analysis (CAMNEA) method. For this purpose, $1 \mathrm{ml}$ of $37 \%$ formaldehyde was added to the rest of the suspension $(15 \mathrm{ml})$, and then the whole volume was stained with $30 \mathrm{ml}$ of acridine orange solution $(0.1 \mathrm{mg} / \mathrm{ml})$ for 5-10 min. The resulting suspension was filtered through a polycarbonate filter, which was then placed on a glass slide. Stained microorganisms were counted using an epifluorescence microscope (Eclipse E200, Nikon, Tokyo, Japan) in 40 randomly selected microscopic fields, and the total number of bioaerosol particles (TNBP) was then determined and expressed as a number of cells in $1 \mathrm{~m}^{3}$ of air $\left(\right.$ cells $\left./ \mathrm{m}^{3}\right)$.

\section{Statistical analysis}

The obtained results were reported as medians together with the concentration range. As all the independent variables were not normally distributed (according to the Shapiro-Wilk statistics), the nonparametric KruskallWallis, Mann-Whitney U and Wilcoxon tests as well as Spearman's rank correlation coefficient were used to confirm statistical importance of the observed relationships. To assess taxonomic diversity between the workplace and 
background samples, the Chi test was also applied. All calculations were performed using Statistica data analysis software system, version 10 (StatSoft, Inc., Tulsa, OK, USA), assuming a value of $\mathrm{p}<0.05$ as statistically significant.

\section{RESULTS}

Table 2 summarizes results of the quantitative analysis of the investigated biological agents in a metal processing plant and in the outdoor background obtained by sampling with the Button Sampler. Median concentration of peptidoglycans was $14.6 \mathrm{ng} / \mathrm{m}^{3}$ and ranged from $5.3 \mathrm{ng} / \mathrm{m}^{3}$ (L5 - storing place) to $53.5 \mathrm{ng} / \mathrm{m}^{3}$ (L2 - hand lathe). In the case of endotoxins, median concentration for the studied workplaces was $0.2 \mathrm{ng} / \mathrm{m}^{3}$ and ranged $0.1-3.1 \mathrm{ng} / \mathrm{m}^{3}$, in the storing place (L5) and grinder (L1), respectively. For both factors, the analysis showed no significant difference in concentration between the sampling points within the factory (Kruskall-Wallis test: $\mathrm{p}>0.05$ ).

Median concentration of viable bacteria was $1.16 \times 10^{3}$ $\mathrm{CFU} / \mathrm{m}^{3}$ and ranged from $2.63 \times 10^{2} \mathrm{CFU} / \mathrm{m}^{3}$ (L5) to $1.28 \times 10^{4} \mathrm{CFU} / \mathrm{m}^{3}$ ( $\mathrm{L} 1$ - grinder). Analysis of the TNBP with the CAMNEA method showed that their median concentration in the plant was $1.81 \times 10^{6}$ cells $/ \mathrm{m}^{3}$, which was about 4 orders of magnitude more than the concentration of viable bacteria (Wilcoxon test: $\mathrm{p}<0.01$ ). There were no significant differences in the concentrations of viable bacteria and TNBP between the workplaces within the studied plant (Kruskall-Wallis test: $\mathrm{p}>0.05$ ).

Qualitative analysis in the studied workplaces revealed presence of 19 bacterial species belonging to 14 genera (Table 3), including 3 species of the genus Corynebacterium, and another 3 species of the genus Staphylococcus, and 2 of the genus Bacillus. In the air there were also found Gram-negative bacteria belonging to the genera: Comamonas, Citrobacter, Pasteurella, Serratia, and Pseudomonas, which may be a source of endotoxins. It was also shown that taxonomic diversity in the plant was significantly higher than in the outdoor background samples $\left(\mathrm{Chi}^{2}\right.$ test $\left.=22.7, \mathrm{p}<0.001\right)$.

Calculations of Spearman's rank correlation coefficient based on the data obtained by the BS showed strong, significant correlations $(p<0.05)$ between endotoxins, viable bacteria $(r=0.75)$ and TNBP concentrations $(r=0.76)$ as well as between PGs and TNBP concentrations $(r=0.72)$ (Table 4).

Size distribution analysis (Figure 1), showed that the highest concentrations of bacterial aerosols in the workplaces occurred in the range 2.1-3.3 $\mu \mathrm{m}$. In the case of endotoxins, an increase of concentrations in 2 ranges of aerodynamic diameters was shown. The 1st was marked for particles of sizes $1.1-3.3 \mu \mathrm{m}$, and it was $3.4 \mathrm{ng} / \mathrm{m}^{3}$, while the $2 \mathrm{nd}-\operatorname{larger}\left(5.5 \mathrm{ng} / \mathrm{m}^{3}\right)$, in the range of 5.8-9 $\mu \mathrm{m}$. Peptidoglycans behaved differently from endotoxins. In the range

Table 2. Concentrations of biological agents in the metal processing plant and outdoor background measured using the Button Sampler

\begin{tabular}{lcc}
\hline \multirow{2}{*}{\multicolumn{1}{c}{ Biological agent }} & \multicolumn{2}{c}{ Concentration } \\
\cline { 2 - 3 } & $\begin{array}{c}\text { metal processing plant } \\
(\mathrm{N}=10)\end{array}$ & $\begin{array}{c}\text { outdoor background } \\
(\mathrm{N}=1)\end{array}$ \\
\hline Peptidoglycans $\left[\mathrm{ng} / \mathrm{m}^{3}\right]$ & $\operatorname{Me}(\mathrm{min} .-\mathrm{max})$ & 8.90 \\
Endotoxins $\left[\mathrm{ng} / \mathrm{m}^{3}\right]$ & $14.60(5.30-53.50)$ & 0.10 \\
Viable bacteria $\left[\times 10^{2} \mathrm{CFU} / \mathrm{m}^{3}\right]$ & $0.20(0.10-3.10)$ & 2.50 \\
Bioaerosol particles (total number) $\left[\times 10^{6} \mathrm{cells} / \mathrm{m}^{3}\right]$ & $11.60(2.63-128.20)$ & 0.02 \\
\hline
\end{tabular}

$\mathrm{N}$ - number of samples for each agent; Me - median; min. - minimal value; max - maximal value. 
Table 3. Qualitative characteristics of bacterial aerosols in the metal processing plant and outdoor background (as measured with the Button Sampler)

\begin{tabular}{lcc}
\hline \multicolumn{1}{c}{ Species and genus } & $\begin{array}{c}\text { Metal } \\
\text { processing } \\
\text { plant }\end{array}$ & $\begin{array}{c}\text { Outdoor } \\
\text { background }\end{array}$ \\
\hline Bacillus cereus & + & \\
Bacillus subtilis & + & \\
Brevibacterium spp. & + & \\
Cellulomonas spp. & + & \\
Citrobacter freundii & + & \\
Comamonas testosteroni & + & \\
Corynebacterium propinquum & + & + \\
Corynebacterium spp. & + & \\
Corynebacterium striatum & + & \\
Kocuria varians & + & \\
Microbacterium spp. & + & \\
Micrococcus spp. & + & \\
Pasteurella spp. & + & \\
Pseudomonas stutzeri & + & \\
Rhodococcus spp. & + & \\
Serratia liquefaciens & + \\
Staphylococcus epidermidis & + \\
Staphylococcus lentus & + \\
Staphylococcus xylosus & + \\
Streptomyces spp. & & \\
\hline
\end{tabular}

of diameters 2.1-9 $\mu \mathrm{m}$ there was a visible gradual increase in the concentration from $10.9 \mathrm{ng} / \mathrm{m}^{3}$ to $18.3 \mathrm{ng} / \mathrm{m}^{3}$. Taking into account aerodynamic sizes $\left(\mathrm{d}_{\mathrm{a}}\right)$ of the dominant groups of bacteria (Table 5), i.e., Gram-positive

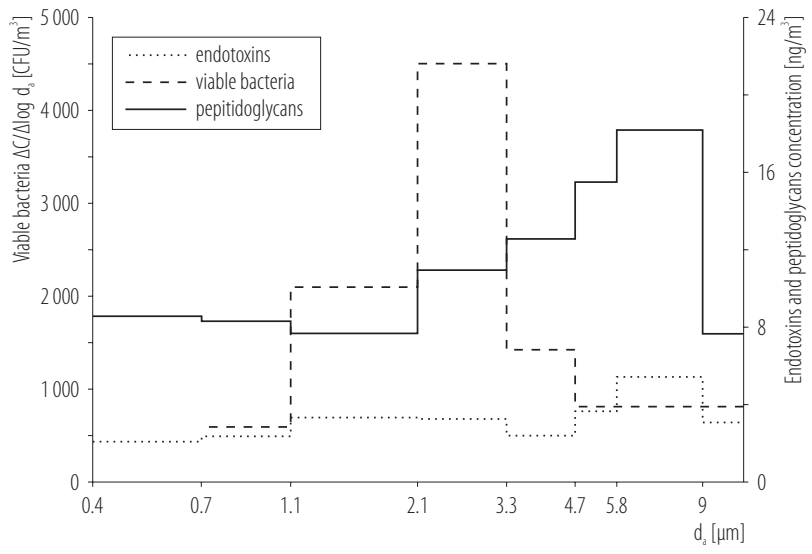

$\mathrm{d}_{\mathrm{a}}$ - aerodynamic diameter; $\Delta \mathrm{C} / \Delta \log \mathrm{d}_{\mathrm{a}}$ - concentration in aerodynamic particle size ranges expressed in a log form.

Fig. 1. Size distributions of the measured bioaerosols in the workplaces in the metal processing plant

$\operatorname{cocci}\left(\mathrm{d}_{\mathrm{a}} \approx 0.8-1 \mu \mathrm{m}\right)$, the particle diameter of which ranges $0.3-2 \mu \mathrm{m}$ and Gram-negative bacteria $\left(\mathrm{d}_{\mathrm{a}} \approx 0.8-\right.$ $0.9 \mu \mathrm{m})$ it can be concluded that they occurred mostly as small aggregates composed of bacterial and/or bacterial and dust particles, whereas endotoxins and peptidoglycans were transported in the air by particles and/or aggregates mainly with bigger $(5.8-9 \mu \mathrm{m})$ aerodynamic sizes.

\section{DISCUSSION}

To the best of our knowledge, in the current study airborne peptidoglycans in the oil mist environment have been analyzed for the first time. The study using the same method for their quantitative assessment (SLP test) in other occupational environment, i.e., among swine farm workers [15]

Table 4. Spearman's rank correlation coefficient analysis for the measured variables in the metal processing plant

\begin{tabular}{lccc}
\hline \multirow{2}{*}{ Variable } & \multicolumn{3}{c}{ Spearman's rank correlation } \\
\cline { 2 - 4 } & 1 & 2 & 3 \\
\hline 1. Endotoxins & 1.00 & & \\
2. Peptidoglycans & 0.41 & 1.00 & 1.00 \\
3. Viable bacteria & $0.75^{*}$ & -0.19 & 0.41 \\
4. Bioaerosol particles (total number) & $0.76^{*}$ & $0.72^{*}$ & \\
\hline
\end{tabular}

* Significant relationship $(\mathrm{p}<0.05)$. 
Table 5. Prevalence of bacterial groups identified in the air samples in the metal processing plant (as measured with the Andersen impactor)

\begin{tabular}{lcl}
\hline \multicolumn{1}{c}{ Bacterial group } & $\begin{array}{c}\text { Prevalence } \\
{[\%]}\end{array}$ & \multicolumn{1}{c}{ Identified genera } \\
\hline Gram-positive cocci & 54.7 & Micrococcus, Staphylococcus, Kocuria \\
Gram-negative rods & 18.6 & Citrobacter, Comamonas, Pasteurella, Pseudomonas, Serratia \\
Non-sporing Gram-positive rods & 16.0 & Corynebacterium, Microbacterium, Brevibacterium \\
Mesophilic actinomycetes & 8.7 & Rhodococcus, Streptomyces \\
Gram-positive bacilli & 2.0 & Bacillus \\
\hline
\end{tabular}

has shown much higher PG concentrations, ranging $26-1695 \mathrm{ng} / \mathrm{m}^{3}$. In turn, using the analysis of muramic acid - a chemical marker of PGs, their average concentrations ranged from $187 \mathrm{ng} / \mathrm{m}^{3}$ in the processing of cotton, through $260 \mathrm{ng} / \mathrm{m}^{3}$ at the slaughterhouse, $800 \mathrm{ng} / \mathrm{m}^{3}$ at a waste sorting plant, to $6268 \mathrm{ng} / \mathrm{m}^{3}$ at granary [16].

To date, a threshold limit value for PGs hasn't been proposed as well as there have been no studies analyzing different parameters of environmental sampling. Scarce epidemiological studies among pig farms workers suggest a positive correlation between concentrations of PGs and the increase of granulocytes in the blood of exposed individuals [23]. Furthermore, an analysis of the immune response using the "whole blood assay" has shown a significant increase in the tumor necrosis factor $\alpha$ (TNF- $\alpha$ ) and interleukin 8 (IL-8) production at PG concentration of $10 \mu \mathrm{g} / \mathrm{ml}$ [24]. On the other hand, inflammatory changes in the lung parenchyma (including lymphoid cell aggregates in alveolar and bronchial compartment) have been found in mice after repetitive intranasal inhalation exposures with peptidoglycans [25].

In our study, concentrations of airborne endotoxins were 4-5 times lower than those of PGs. Moreover, it appeared to be lower than in the other studies conducted in this type of occupational environment as well as below the health-based occupational exposure limit of $90 \mathrm{EU} / \mathrm{m}^{3}$ $\left(\sim 9 \mathrm{ng} / \mathrm{m}^{3}\right)$ established by the Dutch Expert Committee on Occupational Safety in collaboration with the Nordic
Expert Group for Criteria Documentation of Health Risks from Chemicals [14]. For example, Gilbert et al. [6] and Laitinen et al. [11] have reported endotoxin concentrations in the range $1.39-9.3 \mathrm{ng} / \mathrm{m}^{3}$ and of $0.04-600 \mathrm{ng} / \mathrm{m}^{3}$, respectively.

On this background, the results of the present study seem to be affected by the shorter measurement time, due to simultaneous measurement of bacterial aerosols. It is also possible that the final result of the analysis could have been underestimated because of the use of a specific filter type during the measurements. Various studies have shown that the use of glass fiber filters, as it has been done in Laitinen et al. [11] and Gilbert et al. experiments [6], usually contributes to the increase of endotoxin concentrations in comparison to PTFE, polycarbonate (PC) or polyvinyl chloride (PVC) filters used for the same purpose under the same conditions [26].

The results of quantitative and qualitative analyses of bacteria were similar to those that have been observed so far in other studies concerning this type of working environment $[6,11,27]$. However, the CAMNEA method showed that the measurement of TNBP in a much more precise way characterizes microbial contamination than the measurement of only those factors that in the examined environment retain their viability and culturability.

Both living and dead bacterial cells constitute the source of endotoxins (from Gram-negative bacteria) and PGs (from all bacteria), and should be treated as a reservoir 
of immunologically active compounds, which even in small doses may influence workers' health. The results of correlation analysis from our study seem to confirm these observations. In the studied oil mist environment, endotoxins precisely reflected the presence of airborne living and dead bacteria, which is consistent with previous findings in this area [7,28]. The present study has shown, for the first time, that in relation to TNBP, peptidoglycans may play a similar function.

This statement is also supported by the size distribution analysis. The results confirm that in such a working environment, oil mist facilitates transport and aggregation of biological particles. This process is noticeable to endotoxins, which showed a slight increase in concentrations for particles with aerodynamic in diameters ranging 1.1-3.3 $\mu \mathrm{m}$ that corresponds to the most common cells dimensions of Gram-negative bacteria, which constituted approx. $19 \%$ of the identified microorganisms. However, an additional peak observed in the range of 5.8-9 $\mu \mathrm{m}$ probably indicates aggregation of the particles on the surface of mist droplets after death of bacterial cells. Above these size diameters, the concentrations began to fall, due to the lack of a carrier that could transport endotoxins. The surface tension of oil mist particles is insufficient to maintain a compact form of such large molecules. In the case of PGs, the tendency was essentially the same, except for the concentrations in the size range 2.1-9 $\mu \mathrm{m}$, where they increased more uniformly. Above this value, a marked decline in PG levels was also observed.

The occurrence of 2 peaks of endotoxin concentrations is similar to what has been observed in the study of Wang et al. [29], but in that case it has been found for particle sizes of $0.39 \mu \mathrm{m}$ and $2.45 \mu \mathrm{m}$, which were much smaller than those in our study. Appearing differences may be due to 2 main reasons. The 1st is the use of other measuring instruments. Those results were obtained through the use of an electrical low pressure impactor (ELPI) (Dekati, Finland), which involves electrical charging of particles, which enter a low pressure cascade impactor, and subsequently measuring electric current carried by the impacted particles onto the impactor stages in a range 0.029$10.18 \mu \mathrm{m}$ [30]. Thus, it is characterized by high efficiency particles uptake, especially those below $<1 \mu \mathrm{m}[31$ ]. However, in the present study, measurements were performed using the 8-stage non-viable cascade impactor, which can separate particles from $0.4 \mu \mathrm{m}$ to $9 \mu \mathrm{m}$. In addition, the highest efficiency of particle uptake for this device was found in a range of 1.1-4.7 $\mu \mathrm{m}$ [32].

Technological conditions in the factories where bioaerosols have been examined constitute the 2 nd reason influencing the obtained results. As proved by Dasch et al. [33], size distributions of oil mist particles may depend on the type of metal processing technology as well as on the type of cooling lubricant. In the case of the old type machines (they were used in our facility) without covers capturing particles released during production processes, where water-oil emulsions were used, the particles were found mainly in the range $2.5-5 \mu \mathrm{m}$. In contrast, the newer generation machines were dominated by the particles with a diameter of approx. $1 \mathrm{~mm}$.

Based on the obtained results, the place of endotoxins and PGs deposition in the respiratory system may be assessed. In the case of endotoxins, they may impact the area of terminal and secondary bronchi, whereas peptidoglycans can be deposited in the upper respiratory passages in the vicinity of primary bronchi, as well as within trachea and pharynx. Nevertheless, in order to be extrapolated to other occupational and non-occupational environments, the obtained results require a further verification.

\section{CONCLUSIONS}

The metalworking fluids released into the air as oil mist can be an abundant source of peptidoglycans.

Peptidoglycans can be treated as a supporting indicator of bacterial contamination in metal processing plants, 
particularly when the assessment of an immunotoxic potential of microbiological hazards needs to be performed. The proposed method is faster than conventional culturable methods and it allows detection of bacterial contamination even if bacteria's levels are really low.

In order to be extrapolated to other occupational and nonoccupational environments, the obtained results require a further verification.

\section{REFERENCES}

1. Rossmoore HW. Microbial degradation of water-based metalworking fluids. In: Moo-Young M, editor. Comprehensive biotechnology: The principles, applications and regulations of biotechnology in industry, agriculture and medicine. Vol. IV: The practice of biotechnology: Speciality products and service activities. Oxford: Pergamon Press; 1985. p. 249-69.

2. Foxall-Vananken S, Brown JA, Young W, Salmeen I, McClure T, Napier S, et al. Common components of industrial metal-working fluids as sources of carbon for bacterial growth. Appl Environ Microbiol. 1986;51:1165-9.

3. Cyprowski M, Piotrowska M, Żakowska Z, SzadkowskaStańczyk I. Microbial and endotoxin contamination of water-soluble metalworking fluids. Int J Occup Med Environ Health. 2007;20(4):365-71, http://dx.doi.org/10.2478/v10001007-0036-y.

4. Mattsby-Baltzer I, Sandin M, Ahlström B, Allenmark S, Edebo M. Microbial growth and accumulation in industrial metalworking fluids. Appl Environ Microbiol. 1989;55:2681-9.

5. Woskie SR, Virji MA, Kriebel D, Sama SR, Eberiel D, Milton DK, et al. Exposure assessment for a field investigation of the acute respiratory effects of metalworking fluids. Summary of findings. Am Ind Hyg Assoc J. 1996;57:1154-62, http:// dx.doi.org/10.1080/15428119691014279.

6. Gilbert Y, Veillette M, Meriaux A, Lavoie J, Cormier Y, Duchaine C. Metalworking fluid-related aerosols in machining plants. J Occup Environ Hyg. 2010;7:280-9, http://dx.doi. org/10.1080/15459621003680227.
7. Sprince NL, Thorne PS, Popendorf W, Zwerling C, Miller ER, DeKoster JA. Respiratory symptoms and lung function abnormalities among machine operators in automobile production. Am J Ind Med. 1997;31:403-13, http://dx.doi. org/10.1002/(SICI)1097-0274(199704)31:4<403::AIDAJIM5>3.0.CO;2-W.

8. Kriebel D, Sama SR, Woskie S, Christiani DC, Eisen EA, Hammond SK, et al. A field investigation of the acute respiratory effects of metal working fluids. I. Effects of aerosol exposures. Am J Ind Med. 1997;31:756-66, http://dx.doi. org/10.1002/(SICI)1097-0274(199706)31:6<756::AIDAJIM13>3.0.CO;2-X.

9. Sigsgaard T, Bonefeld-Jorgensen EC, Hoffmann HJ, Bønløkke J, Krüger T. Microbial cell wall agents as an occupational hazard. Toxicol Appl Pharmacol. 2005;207:S310-9, http://dx.doi.org/10.1016/j.taap.2004.12.031.

10. Ławniczek-Wałczyk A, Górny RL. Endotoxins and $\beta$-glucans as markers of microbiological contamination - Characteristics, detection, and environmental exposure. Ann Agric Environ Med. 2010;17:193-208.

11. Laitinen S, Linnainmaa M, Laitinen J, Kiviranta H, Reiman M, Liesivouri J. Endotoxins and IgG antibodies as indicators of occupational exposure to the microbial contaminants of metal-working fluids. Int Arch Occup Environ Health. 1999;72:443-50, http://dx.doi.org/10.1007/ s004200050397.

12. Kapoor R, Selvaraju SB, Yadav JS. Extended tracking of the microbial community structure and dynamics in an industrial synthetic metalworking fluid system. FEMS Microbiol Ecol. 2014;87:664-77, http://dx.doi.org/10.1111/15746941.12254.

13. Liebers V, Brüning T, Raulf-Heimsoth M. Occupational endotoxin-exposure and possible health effects on humans. Am J Ind Med. 2006;49:474-91, http://dx.doi.org/10.1002/ ajim.20310.

14. Health Council of the Netherlands. Endotoxins. Healthbased recommended occupational exposure limit. The Hague: The Council; 2010. 
15. Jolie R, Bäckström L, Gunderson P. Airborne contaminants and farmers health in swine farms with high and low prevalence of respiratory diseases in pigs. Ann Agric Environ Med. 1998;5:87-92.

16. Laitinen S, Kangas J, Husman K, Susitaival P. Evaluation of exposure to airborne bacterial endotoxins and peptidoglycans in selected work environments. Ann Agric Environ Med. 2001;8:213-9.

17. Góra A, Mackiewicz B, Krawczyk P, Golec M, Skórka C, Sitkowska J, et al. Occupational exposure to organic dust, microorganisms, endotoxin and peptidoglycan among plants processing workers in Poland. Ann Agric Environ Med. 2009;16:143-50.

18. Kobayashi T, Tani T, Yokota T, Kodama M. Detection of peptidoglycan in human plasma using the silkworm larvae plasma test. FEMS Immunol Med Microbiol. 2000;28: 49-53, http://dx.doi.org/10.1111/j.1574-695X.2000.tb01456.x.

19. Myhre AE, Aasen AO, Thiemermann C, Wang JE. Pepidoglycan - An endotoxin in its own right? Shock. 2006;25:22735, http://dx.doi.org/10.1097/01.shk.0000191378.55274.37.

20. Henne E, Campbell WH, Carlson E. Toxic shock syndrome toxin-1 enhances synthesis of endotoxin-induced tumor necrosis factor in mice. Infect Immun. 1991;59:2929-33.

21. Cyprowski M, Ławniczek-Wałczyk A, Górny RL. Peptidoglycans in cutting fluids - A good indicator of bacterial contamination? Ann Agric Environ Med. 2014;21:256-8, http:// dx.doi.org/10.5604/1232-1966.1108586.

22. Xu Z, Yao M. Analysis of culturable bacterial and fungal aerosol diversity obtained using different samplers and culturing methods. Aerosol Sci Technol. 2011;45:1143-53, http://dx.doi.org/10.1080/02786826.2011.582195.

23. Zhiping W, Malmberg P, Larsson BM, Larsson K, Larsson L, Saraf A. Exposure to bacteria in swine-house dust and acute inflammatory reactions in humans. Am J Respir Crit Care Med. 1996;154:1261-6, http://dx.doi.org/10.1164/ ajrccm.154.5.8912733.

24. Harting JR, Gleason A, Romberger DJ, von Essen SG, Qiu F, Alexis N, et al. Chronic obstructive pulmonary disease patients have greater systemic responsiveness to ex vivo stimulation with swine dust extracts and its components versus healthy volunteers. J Toxicol Environ Health A. 2012;75: 1456-70, http://dx.doi.org/10.1080/15287394.2012.722186.

25. Dusad A, Thiele GM, Klassen LW, Gleason AM, Bauer C, Mikuls TR, et al. Organic dust, lipopolysaccharide, and peptidoglycan inhalant exposures result in bone loss/disease. Am J Respir Cell Mol Biol. 2013;49:829-36, http://dx.doi. org/10.1165/rcmb.2013-01780C.

26. Spaan S, Heederik DJ, Thorne PS, Wouters IM. Optimization of airborne endotoxin exposure assessment: Effects of filter type, transport conditions, extraction solutions, and storage of samples and extracts. Appl Environ Microbiol. 2007;73:6134-43, http://dx.doi.org/10.1128/ AEM.00851-07.

27. Liu HM, Lin YH, Tsai MY, Lin WH. Occurrence and characterization of culturable bacteria and fungi in metalworking environment. Aerobiologia. 2010;26:339-50, http://dx. doi.org/10.1007/s10453-010-9169-8.

28. Abrams L, Seixas N, Robbins T, Burge H, Muilenberg M, Franzblau A. Characterization of metalworking fluid exposure indices for a study of acute respiratory effects. Appl Occup Environ Hyg. 2000;15:492-502, http://dx.doi. org/10.1080/104732200301287.

29. Wang H, Reponen T, Lee SA, White E, Grinshpun SA. Size distribution of airborne mist and endotoxin-containing particles in metalworking fluid environments. J Occup Environ Hyg. 2007;4:157-65, http:/dx.doi.org/ $10.1080 / 15459620601144883$.

30. Kulkarni P, Baron PA, Willeke K, editors. Aerosol measurement. Principles, techniques, and applications. New Jersey: John Wiley \& Sons, Inc.; 2011, http://dx.doi. org/10.1002/9781118001684.

31. Wang H, Reponen T, Martuzevicius D, Grinshpun SA, Willeke K. Aerosolization of fine particles increases due to microbial contamination of metalworking fluids. J Aerosol Sci. 2005;36:721-34, http://dx.doi.org/10.1016/j.jaerosci. 2004.11.007. 
32. Roberts DL, Mitchell JP. The effect of nonideal cascade impactor stage collection efficiency curves on the interpretation of the size of inhaler-generated aerosols. AAPS PharmSciTech. 2013;14:497-510, http://dx.doi.org/10.1208/s12249-013-9936-2.
33. Dasch J, d'Arcy J, Gundrum A, Sutherland J, Johnson J, Carlson D. Characterization of fine particles from machining in automotive plants. J Occup Environ Hyg. 2005;2:60925, http://dx.doi.org/10.1080/15459620500377659.

This work is available in Open Access model and licensed under a Creative Commons Attribution-NonCommercial 3.0 Poland License - http://creativecommons.org/ licenses/by-nc/3.0/pl/deed.en. 